GLOBAL JOURNAL OF EDUCATIONAL RESEARCH VOL 14, 2015: 31-39

COPYRIGHT@ BACHUDO SCIENCE CO. LTD PRINTED IN NIGERIA. ISSN 1596-6224 www.globaljournalseries.com; Info@globaljournalseries.com

\title{
ABSTRACT AND BIBLIOGRAPHY AS RETRIEVAL DEVICES AND STUDENTS UTILISATION OF INFORMATION RESOURCES IN UNIVERSITY OF CALABAR LIBRARY
}

\author{
FIDELIS E. INYOKWE AND JULIANA AGUNOBI
}

(Received 22, August2014; Revision Accepted 19, September 2014)

\begin{abstract}
The study investigates the relationship between students' utilisation of information resources through the consultation of information retrieval devices: Abstracts and bibliographies in university of calabar library. The survey research design was used for the study. The population of the study comprised library-registered students of university of calabar. The sample size used for the study consisted of 1523 library-registered students. In order to carry out the investigation successfully, two hypotheses were formulated to guide the study. The instrument captioned, 'Retrieval Devices and Students' Utilization of Information Resources Questionnaire (RDSUIRQ)" was used for data collection. The instrument was ensured to be valid and reliable. Copies of the questionnaire were administered to the subjects and data were collected and analyzed using Pearson Product Moment Correlation. The result showed significant positive relationships between information retrieval devices of Abstracts and Bibliographies and students' utilization of information resources in university of calabar library. It therefore follows from this finding that abstracts and bibliographies play a significant role in the utilization of library resources. Based on the findings, recommendations were made, one of which was that librarians should ensure that retrieval devices in their libraries are properly managed for optimum utilization of information resources by students.
\end{abstract}

KEYWORD: Abstracts and Bibliographies, Retrieval Devices, Students Utilization of Information Resources in University of Calabar Library.

\section{INTRODUCTION}

From the origin, man has displayed high quest for knowledge and information. This informed the establishment of schools and at various levels in our society. Universities particularly are primarily established to train manpower for the industrial and managerial development of the nations. The achievement of this intention is highly dependent upon the provision of information resources. However, Meadow (1992) observed that it is not enough to provide these resources without making them useful to those who need them.

Information is widely recognized as a catalyst for both national and personal development. The wealth of information resources in existence in university libraries today is tremendous. The retrieval and utilisation of these information resources are very important for the achievement of academic goals of the universities. Therefore, retrieval devices such as abstracts and bibliographies should be treated with the seriousness they deserve in order to attract students use of information resources in our university libraries.

Pampam (1998) affirms that a nation that can provide better information service to its people, will be in a position to cope with the problems of everyday life, improve human relationship in her own community and between diverse cultures and traditions, and thus

Fidelis E. Inyokwe, The University Library, University of Calabar, Nigeria

Juliana Agunobi, The University Library, University of Calabar, Nigeria 
contribute to better understanding and world cooperation. Utilisation of information resources must be considered a major feature in the improvement of the quality of life for each individual.

Igbo (2000) asserts that all living species survive by using their senses to gather information about their environment. This information appears in two forms- print and nonprint. The print form may be book, journal or periodical, while the non-print form may be compact disc (CD), diskette, cassette, slide, tape or flash drive. This information gathered is translated into actions which are advantageous to their well-being and survival. McHale (2005) therefore, warns that any obstacles from any quarter to deprive them of this vital ingredient, shall render them impotent of the knowledge that they are supposed to have. This is why custodians of information resources must create retrieval devices like Abstracts and Bibliographies, to give opportunities to users to effectively utilize the resources provided by their libraries.

Nigeria with an estimated population of 150 million (National Population Commission, 2006), is said to be the most populous African country and with the largest number of universities, which require ready access to recorded information to carry out instructional and or research duties effectively. One of the major agencies to carry out these bibliographical services in the country is the university library.

As the volume of information resources continues to grow, the problem of how to retrieve them for use increases. Aguolu and Aguolu (2002) attribute these problems to:

(a) Users' inability to articulate their needs to the library staff.

(b) Inadequacy of bibliographic access to the content of the library, owing to poor indexing system of the catalogue. nadequacy of circulation policy, poo shelving method and lack of guides to the library organization.

Unnecessary physical and administrative barriers imposed upon the use of library collections by the library management $(P$. $67)$. The authors conclude that the more accessible library materials are, the more likely the number of students that would patronise the resources provided.

The usefulness of abstract in any library was identified by Okafor (2006). The research looks at abstract as veritable tool in the retrieval of information resources by users. The author states that abstract makes the retrieval of information easy for students, researchers, and other lovers of knowledge. The author stresses that abstract is an essential retrieval device for persons seeking to use information resources on a particular subject. This will enable users to search a large number of information resources within a short time.

Librarians as mediators between the students and their information resources are expected to design retrieval devices that are compatible with the needs of the students and their quest to satisfy such needs. The efforts made at creating retrieval devices worldwide according to Harvey (1992) is to promote use of the world's accumulation of knowledge. Equally, most universities in developing countries including those in Nigeria have taken queue to encourage the use of retrieval devices to utilise information resources in their libraries through orientation, public lectures and course work. The extent to which library users make use of these devices needs to be understood and encouraged as the case may be.

\section{Statement of the problem}

It is common knowledge in Nigeria that there are many students who are almost graduating or may have graduated from the university who did not have adequate knowledge of the library or who even did not use it. This on the whole, questions the essence of setting up libraries in the institutions of learning as academic achievement has become a shadow of what it is supposed to be.

To state succinctly, the university library plays important role in furnishing students with information that results in the holistic development of the society. It is expected that learners make maximum use of information resources provided by this library to excel in various fields of study. But this seems not to be so. In the face of this scenario of poor use of library with resultant poor academic achievement as observed for some time now, (Cochrane, 1991; Okon, 2007), it raises the doubt of attaining the Millennium Development Goals (MDGs) as anchored by the present Nigerian leaders. The need to explore the root causes of this ugly trend with the view to increasing learners' use of the library resources should be explored. This would be in line with the common assertion that "only 
good readers of today can be good leaders of tomorrow".

The contemporary poor utilisation of library resources is known to cause many ills, prominent among which is poor academic achievement among students (Aguolu \& Aguolu, 2002). The quality of university education is usually determined by the performance of graduates produced therein. Poor academic achievement among students as a result of poor utilisation of library resources as observed by Aguolu and Aguolu (2002) and the researcher presently, is a serious threat to the quality of graduates produced in Nigerian universities. This situation needs to be urgently addressed. It is only by addressing this that the quality of graduates produced could be improved. Thus, this study was designed to address questions such as: what relationship exist between retrieval devices such as abstract and bibliographies, and students' utilisation of information resources? What can be done to enhance students' utilisation of information resources in this library?

\section{Purpose of the study}

The purpose of this study is to determine the relationship between retrieval devices and students' utilisation of information resources in University of Calabar library. In specific terms, the objectives of the study are to determine the relationship between.

1. The use of abstract and students' utilisation of information resources in university of Calabar library.

2. The use of bibliographies and students' utilisation of information resources in university of Calabar library.

\section{Significance of the study}

Scholars, librarians and the society at large stand to benefit from this study. This is because learning shall be made simple for the students through awareness on the use of retrieval devices; librarians' job stress shall be reduced and Nigeria could achieve the objectives of setting up the universities.

This study should be of benefit to scholars as it will help simplify their laborious tasks of searching, retrieving and utilising information resources in our libraries. Stated differently, if library users get proper understanding of the retrieval devices, how to use them and actually put them to use (which is the thrust of this work), they will likely spend minimal time but have higher achievement from their efforts in the use of libraries. This will on the whole lead to higher academic achievement among our learners.

Librarians should on their part benefit from this study as their jobs in the libraries stand to be simplified. In other words, if library users have proper understanding on how to access what materials and at what point in the library, librarians may definitely have less work to do in our libraries.

The society at large may not be left out from benefiting from this study. For instance, if librarians have less work to do, their energies can be channelled into other productive ventures to the benefit of the larger society. In addition, if higher academic achievement is recorded by our students as a result of the ease in the use of the library, there will be no denying the fact that our society will be closer towards attaining the Millennium Development Goals (MDGs) and Vision 20: 2020 of the federal government.

\section{Hypotheses}

Two hypotheses were postulated and tested at .05 level of significance. They are:

$\mathrm{H}_{\mathrm{O} 1}$ : There is no significant relationship between the use of abstract and students' utilization of information resources in university of Calabar library.

$\mathrm{H}_{\mathrm{O} 2}$ : There is no significant relationship between the use of bibliographies and students' utilization of information resources in University of Calabar.

\section{CONCEPTUAL CONSIDERATIONS}

\section{Abstracts and students utilization of information resources}

Abstract is one of the retrieval devices identified in this study. Manzer (2002) defines abstract as a summary of a publication or article that is accompanied by an adequate bibliographical description, to enable the student have access to the utilisation of publications or articles at ease. This service is intended to give opportunity to students to consider from a mass of publications whether a particular item is good enough to solve his information problem.

Bernier (2002) points out nine reasons why abstracts are useful to students' utilisation of information resources in university libraries. 
1. Due to large volumes of published items yearly, it is difficultand sometimes impossible for a student to locate them. Abstracts therefore facilitate their use.

2. Documents are written in many languages, abstracts help to translate the document to their (students) own language.

3. Abstracts in many cases substitute for the original literature.

4. Abstracts save the time of the student in searching for literature through reading or scanning the abstract.

5. Classified abstracts in published journals bring together guides to large volumes of knowledge.

6. Retrospective searches are greatly aided by classified abstracts.

7. Abstracts help in accuracy and selection of literature to be read more than that of selection from titles of annotations.

8. Abstracts facilitate indexing processes.

9. Abstracts facilitate the organisation of articles, bibliographies, reviews and talks.

Document analysis makes a significant contribution to communication and information flow (Rowley, 1988). The author identifies abstracts as one of those vital components that facilitate such communication link between the student and the library resources. Abstract organises the literature so that students can locate and use information documents in libraries more quickly.

Round (1986) decides to embark upon the preparation of abstracts in the topic "solidliquid flow". The author's intention of embarking upon this was to bring together in a comprehensive fashion all the reported theoretical and experimental work in the field of solid liquid flow with specific emphasis on the flow in pipes, tubes and capillaries. This action is as a result of the yearly increases of literature in the field which makes it difficult for students to use any material on the topic. The preparation of these abstracts has, in no small measure created an avenue for students to select and use interested material bothering on the topic.

Tyckoson (1991) asserts that abstracts have served as the primary access point to library based information resources. The author further stressed that abstract principal role has been to assist students to know the contents of a document and their potential relevance. Abstract as a retrieval device helps in the use of information resources in university libraries, aid in the selection of document as well as help to avoid delay in student's research activity.

The role of abstract is to help the students to quickly ascertain the subject matter of library resources. Weihs (2004) submits that an abstract is a brief summary of a work in a particular subject or discipline. Abstract, the author continues, always appears at the beginning of an article. This would help the student in the selection of topics for research. Abstract allows a student to sift through large quantities of information resources that would enable him to decide which one would be relevant to his research needs.

Weihs (2004) also identifies the standard for writing an abstract about an article to be between 100 to 500 words. This implies that a particular abstract considered for an article should not exceed a page. Weihs (2004) added that an abstract may or may not have the section title "abstract" explicitly listed as part of the material context. However, they are sectioned logically as an overview of what appears in the document. The author concludes that an abstract is a short summary of a work placed prior to the introduction and often set apart from the body of the paper which is sometimes with a different line justification from the rest of the article.

Lehner (1998) agrees with the role abstract plays in the use of information resources. He had used an asbtract to discover a solution to the construction of new detectors in gravitational radiation in the United States, Europe and Japan. The author gave an example of the abstract used to discover solution to the problem as "the science abstracts".

\section{Bibliographies and Students Utilisation of Information Resources}

Bibliographies are systematic listing of information resources on a given subject and or by a given author. University of Calabar library information guide, (unpublished), identifies information resources to include books, periodicals, pictures, maps, manuscripts and any other media of communication that exist. Bibliographies are not only valuable, but also essential, in that they provide direction to students to embark on their research needs.

Aquolu and Aguolu (2002) maintained that the primary users of information resources in University libraries are students of the universities. And that any realistic bibliographic organisation designed to provide direction to the 
effective use of library resources must depend on the librarian's knowledge of the needs of these diversified users (students). The authors agree that librarians as mediators between students and the information environment require special skills to design bibliographic systems that will link students to the use of information resources of their needs.

The chief concern of a university library is to make the materials instruction and research bibliographically and physically useful (Brough, 1983). The author however argues that location of records through bibliographies are not synonymous with use of the content of the resources. That subject bibliographies are intellectual channel to recorded knowledge. A student's inability to understand the content of a book may have nothing to do with the intellectual accessibility of the book per se, but may be due to the student's limited powers of comprehension.

The major responsibility of a librarian is to ensure effective utilisation of his library holding. However, Greg (2002) argues that the responsibility of a librarian extends beyond providing effective bibliographic access to the use of his library, but also to the resources of other libraries within the country to promote library cooperation as well as providing unlimited opportunities to students who may not find all they need in their university libraries. The author explains that the reason for the uncontrolled proliferation of departmental, faculty and institute libraries in our university setting in Nigeria and the failure of the universities librarians to create and promote union catalogues have made it difficult for students to have access to the use of other universities libraries holdings.

However, Aguolu (2002) advises that bibliographies should not be compiled for the sake of doing so. But that only materials that have relevance to the needs of students should be selected. He admitted that some documents which may be ignored may be relevant to the needs of students, and further advised that librarians should take out time to study the needs of students before embarking on such compilation. It is by so doing that a bibliography compiled can be said to be comprehensive.

Belanger (2003) traces the origin of bibliography to the Greek word bibliographic, which means book writing. Accordingly, bibliography is the systematic list of books and other works such as journal articles, which enables a student to access them easily.
Bibliographic works differ in the amount of details, depending on the purpose, (Harris, 2004) establishes. This is categorized into enumerative and analytical bibliographies. Enumerative bibliography is a list of writings that share a common factor which may be by topic, language, period, or some other theme. Analytical bibliography is therefore the close examination of a book as a physical object, recording its size, format binding and so on. A bibliography, the author concludes, may be arranged by author's name, topic, subject, year and place of publication. All these are designed to assist the students to use their information resources easily.

International Federation of Library Associations and Institutions (IFLA's) objectives in promoting Universal Availability of Publications (UAP) in libraries is for the utilisation of information resources by readers generally and university students in particular (Nweke, 1991). Bibliography as one of the retrieval devices so promoted by IFLA is to provide students with the maximum opportunities to use the available information resources globally. Maximum access to information resources through bibliographies the author stressed, is the only panacea to better utilisation of information resources by students in university libraries.

Iwuji (2005) takes a historical look at bibliographic control of these and dissertations in Nigeria. The research is aimed at creating effective retrieval devices for coping with the ever increasing nature of these knowledge documents. The research applauds efforts of individuals, institutions and organisations in the past to promote bibliography of information resources. These early attempts failed woefully because they attempted a comprehensive control of world literature without realising the national and international agencies with a co-ordinating centre that constitute a total system. Research output of Nigerian universities is a hidden treasure, unknown and therefore underutilised. The author imagines the amount of unconscious duplication that is going on in the expensive enterprise and the extent of undue use owing to lack of bibliography. The research recommends that the national library of Nigeria should resuscitate the abandoned National Information and Documentation Centre (NIDOC) established for this purpose so that the problem encountered in this regard would be a thing of the past. 


\section{METHODOLOGY}

The study adopted the survey research design. Tools such as questionnaire, observation and interview were used in data collection. A sample of 1523 respondents was selected, data was collected from them and inferences made to cover the entire population involved in the study. They were selected using accidental sampling technique. This approach is applicable since the number of respondents is large, coupled with the fact that not all of them could be in the library at the time the researcher would visit the library. In other words, the library users met by the researcher in the library at the time of data collection were used. However, ten per cent $(10 \%)$ of the registered library users were investigated

\section{Instrumentation}

A structured questionnaire designed by the researcher was used to collect the needed data in this study. This is titled "Retrieval Devices and Students Utilisation of Information Resources Questionnaire (RDSUIRQ)". It is a 5 point Likert scale questionnaire made up of 28 items for the independent variables and 24 items for the dependent variable. The response options fall between figure SA to SD, where SA represents
Strongly Agree, A represents Agree, U represents Undecided, D represents Disagree and SD represents Strongly Disagree.

The items in the questionnaire were in a statement form. Respondents were required to indicate by placing a tick $(\sqrt{ })$ at the appropriate column their extent of use of the corresponding retrieval device or information resources as conveyed by the response options. The instrument was ensured to be both valid and reliable.

\section{Data Analysis}

Copies of the instrument administered were collected, scored and coded by the researcher for statistical analysis. The mean $(x)$ and Standard Deviation (SD) of the respondents on the variables involved in the hypotheses were computed.

Pearson correlation analysis was carried out to measure the relationship between the two variables in each hypothesis.

\section{Hypothesis One}

There is no significant relationship between the use of abstract and students' utilisation of information resources in University of Calabar Library. Pearson product Moment Correlation statistics was employed to test this hypothesis. The result of the analysis is shown in Table 1.

Table 1

Result of Pearson Product Moment Correlation analysis of the relationship between the use of abstract and students' utilisation of information resources in university of calabar library

\begin{tabular}{lrrrccc}
\hline \hline Variable & $\mathbf{X}$ & SD & $\begin{array}{c}\sum \mathbf{x} \\
\sum \mathbf{y}\end{array}$ & $\begin{array}{c}\sum \mathbf{x}^{2} \\
\sum \mathbf{y}^{2}\end{array}$ & $\sum \mathbf{x y}$ & rxy \\
\hline Use of abstract & 83.67 & 10.73 & 130301 & 14904545 & 13005565 & $0.532^{*}$ \\
$\begin{array}{l}\text { Information } \\
\text { utilisation }\end{array}$ & & & & & & \\
\hline \hline
\end{tabular}

${ }^{*} \mathrm{P}<0.05, \mathrm{df}=1521$, critical $r=0.060$

From Table 1, the calculated r-value is 0.532 . This was found to be greater than the critical $r$ value of 0.060 at 0.05 level of significance with 1521 degrees of freedom. On the basis of this, the null hypothesis was rejected. This means that there is a significant relationship between the use of abstract and the utilisation of information resources.

\section{Hypothesis Two}

There is no significant relationship between the use of bibliographies and the utilisation of information resources in university of Calabar library.

This was tested using Pearson Product Moment Correlation statistics as shown in Table 2. 


\section{Table 2}

Result of Pearson Product Moment Correlation analysis of the relationship between the use of bibliographies and students' utilization of information resources in University of Calabar library.

\begin{tabular}{|c|c|c|c|c|c|c|}
\hline Variable & $\mathbf{X}$ & SD & $\sum_{\sum \mathbf{x}} \mathbf{x}$ & $\begin{array}{l}\sum x^{2} \\
\sum v^{2}\end{array}$ & $\sum x y$ & rxy \\
\hline Use of bibliographies & 83.39 & 10.82 & 130904 & 14784362 & 12101016 & 0561 * \\
\hline $\begin{array}{l}\text { Information } \\
\text { utilization }\end{array}$ & 81.11 & 11.31 & 128780 & 14604908 & טדם שותו & ודט. \\
\hline
\end{tabular}

${ }^{*} \mathrm{P}<0.05, \mathrm{df}=1521$, critical $r=0.060$

In Table 2, the calculated r-value is 0.561 which is greater than the critical r-value of 0.060 at 0.05 level of significance with 1521 degrees of freedom. On this basis, the null hypothesis is rejected. This means that a significant relationship exists between the use of bibliographies and students' utilisation of information resources in university of Calabar library.

\section{DISCUSSION OF RESULTS}

The analysis of the data collected on the first hypothesis of the study showed that a significant positive relationship exists between the use of abstract by students and the utilisation of information resources in university of Calabar library. Consequently, the higher the measure of use of abstract, the more information resources in the library are utilised. The implication of this finding is that the utilisation of information resources in the library is determined by the use of abstract. The higher the use of abstract, the better the utilisation of information resources and vice versa.

This finding lends credence to the work of Tyckoson (1991) who asserted that abstracts have served overtime as the primary access point to library based information resources. According to him, the measure of a researcher's use of abstract in the library determines the success they would record in meeting their library need. Similarly, this finding is supportive of the works of Manzer (2002) and Weihs (2004) who both saw abstract and its usage in accessing information resources in the libraries to be very indispensable. The two scholars both described abstracts as summaries of publications that are accompanied by adequate bibliographical descriptions with the potentials to enable students have access to publications at ease and quickly too.

From the findings of this study, it can be seen that abstracts play important role as retrieval devices. Thus, there is no denying the fact as observed in this study that the usage determines the rate of a library user's utilisation of information in the library. The higher the use, the more the indirect utilisation of information resources.

The second hypothesis of the study, was also analysed using Pearson Product Moment statistics at 0.05 level of significance. Result of the analysis was that a significant positive relationship exists between the use of bibliographies by library users and the utilisation of information resources in university of Calabar library. Specifically, the test showed that a positive correlation exists between the use of bibliographies by students and the utilisation of information resources.

The implication of this finding is that the utilisation of information resources in the university of Calabar library is significantly dependent on the use of bibliography. The more students make use of the device, the more access they have to information resources in our libraries.

This aspect of the finding lends support to Belanger (2003) who states that bibliography is the systematic list of books and other works such as journal articles in such a way that it increases students chances of having access to such materials. He notes that when the retrieval device is available and library users make high use of it, it affords them the opportunity to utilise more information resources in the library than the device. This position was also held by Harris (2004) which further lends supports to the present finding that the use of bibliographies influences the utilization of information resources 
in libraries. Thus, he concluded that there is a relationship between the two variables.

\section{CONCLUSION}

From the findings of this study, the grossly inadequate use of libraries by students is traceable to observable factors. These factors revolve around the retrieval devices used in the library.

For instance, the findings in this study show that poor use of abstracts and bibliographies by library clients is a significant cause of the underutilization of information resources in University of Calabar library. As a result of this, there is grossly a significant lack in the holistic development of learners in University of Calabar and eventual graduates in our society. It may well be that this has equally affected the socio-economic and socio-political development of our society.

Similarly, the quality of our university education, and the overall performance of its products are partly tied to the ineffective or poor use of information retrieval devices such as abstracts and bibliographies in university of Calabar library. This has accounted for the inadequate utilization of information resources from the library with resultant crippling of the nation's economy in all spheres. It is on the whole, on the reversal of this negative trend that the quality of students graduating from universities in Nigeria will be on a proper match towards the attainment of the Millennium Development Goals (MDGs), the vision 20:2020 and the transformation agenda as anchored by our current political leaders.

\section{RECOMMENDATIONS}

Based on the findings of the study, the following recommendations were made:

1. Librarians should ensure that retrieval devices in their libraries are properly managed for students access to I nformation utilisation.

2. Using the library is something that has to be learned. Adequate orientation should be given to students on retrieval devices on the use of information resources.

3. Periodic staff training should be carried out to equip them on the challenges pose by students in the utilisation of information resources in their libraries.

\section{REFERENCES}

Aguolu, C. C and Aguolu, I. E., 2002. Libraries and Information Management in Nigeria: Seminal Essays on Themes and Problems. Maiduguri: Ed-Linform Services.

Belanger, Tierry 2003. "Descriptive Bibliography" Bibliographical Society of America. http://jnul.huji.ac.il/ imhm/ catalog. htm.

Bernier, C. L., 2002 In Encyclopedia of Library and Information Science I, 16-17. New York: Marcel Dekker.

Brough, K., 1983. Scholar's Workshop: Evolving Conception of Library Service. Urbana: University of Illinois Press.

Cochrane, P. A., 1985. Redesign of Catalogues and Indexes for Improved Online Subject Access: Selected Papers of Pauline A. Cochrane. Phoenix Arizona 85004-1483: The Oryx Press.

Greg, W.W 2002. What is Bibliography? In Aguolu, C.C., and Aguolu, I.E., Libraries in Information Management: Seminal Essays on Themes and Problems. Maiduguri: ED- L inform Services.

Harris, Neil 2004. Analytical Bibliography: An Alternative Prospectus. Http"//inul.ac.il/imhm/catalog.htm.

Harvey, J. F 1992. Comparative and International Library Science. Metuchen, N. J., The Scarecrow Press.

Igbo, A., 2000. Introduction to Human Learning. Calabar: Ushie Printing and Publishing.

Iwuji, H. O. M., 2005 "Bibliography Control of Theses and Dissertations in Nigeria" Nigerian Library and Information Science Trends 3 (1\& 2): 25-33.

Lehner, L., 1998. Gravitational Radiation from Black Hole Spacetimes. Ph.D Dissertation, University of Pittsburgh. http://en.wikipedia. org/wiki/index

Manzer, B. M 2002. The Abstract Journal. Metuchen, N.J., The Scarecrow Press. 
McHale, J., 2005. The Changing Information Environment. In Tom Stonier. The Microelectronic Revolution, Soviet Political Structure and the Future of East West

Relation. www.emeraldinsight.com/ journals:htm

Meadow, C.T., 1992. Text Information Retrieval Systems. $2^{\text {nd }}$ ed. San Diego: Academic Press.

National Population Commission 2006. Nigeria: State and Local Government Area Demographic Profile, 1991-2010. Abuja: National Population Commission.

Nweke, Ken M.C., 1991. "Universal Availability of Publications (UAP): A case Study of Devices for Access to Information Resources of Nigerian Special Libraries". African Journal of Library, Archives and Information Sciences 1(2): 99-105.

Okafor, V.N., 2006. "Abstract and Index Publications Guide to Information Retrieval" The Research Librarian: Journal of the Nigerian Library Association, Abia State Chapter 1(1): 6069.

Okon, Henry I. 2007. Information Retrieval Techniques. In Etim, F. E and Nssien, F. U., (eds). Information Literacy for Library Search. Uyo: ABAAM Publishing.

Pampam, M.A., 1998. "The Role of National Library of Nigeria in National Information System (NATIS)". Nigerbiblios 3(4): 1718.

Round, G. F., 1986. Solid Liquid Flow Abstracts Volume 3. New York: Gordon and Breach.

Rowley, J. E., 1988. Abstracting and Indexing. $2^{\text {nd }}$ ed. London: Clive Bingley.

Tyckoson, D. A., 1991. Enhancing Access to Information: Designing Catalogs for the $21^{\text {st }}$ Century. New York: The Haworth Press.

Weihs, Daniel 2004. Abstracts Summary. Haifa 32000: License Biomed Central. 